\title{
FOXP3 Promoter polymorphism (-3499 A/G) is not associated with osteoarthritis in a Turkish population
}

\section{Türk popülasyonunda FOXP3 geni promotor polimorfizmi (A-3499G) osteoartit ile ilişkili değildir}

Nilgun Cekin ${ }^{1}$, Ergun Pinarbasi ${ }^{1}$, Gonca Donmez ${ }^{2}$, Aslihan Esra Bildirici ${ }^{1}$, Zekeriya Oztemur ${ }^{3}$, Serdal Arslan $^{1}$, Okay Bullut ${ }^{3}$

${ }^{1}$ Cumhuriyet University, Faculty of Medicine, Department of Medical Biology, Sivas

${ }^{2}$ Omer Halis Demir University, Faculty of Medicine, Department of Medical Biology, Nigde

Cumhuriyet University, Faculty of Medicine, Department of Orthopedics and Traumatology, Sivas

Corresponding author: Ergun Pinarbasi, Cumhuriyet University, Faculty of Medicine, Department of Medical Biology, 58140, Sivas, Turkey.

E-mail: epinar@cumhuriyet.edu.tr

Received/Accepted: August 17.2017 / October 30, 2017

Conflict of interest: There is not a conflict of interest.

\section{SUMMARY}

Objective: In this study we aimed to find out whether FOXP3 promoter region $-3499 \mathrm{~A} / \mathrm{G}$ polymorhism was associated with osteoarthiritis in a Turkish population.

Method: The study group consists of 50 patients in 3rd stage and 100 patients in 4th stage osteoarthiritis and control group consists of 150 healthy individuals. FOXP3 genotypes were examined by PCR-RFLP method.

Results: Our results show that there is no statisticially significant association between osteoarthiritis and FOXP3 $3499 \mathrm{~A} / \mathrm{G}$ polymorphism. The wild type AA genotype was $63 \%$, polymorphic AG was $31 \%$ and GG was $6 \%$ in the control group, while they were $56 \%, 37 \%$ and $7 \%$ in the study group respectively.

Conclusions: Osteoarthiritis was seen higher in women than that of men in our study which is compatible with the results of previous results.

Keywords: FOXP3, Osteoarthritis, promoter, polymorphism

\section{ÖZET}

Amaç: Bu çalışmada FOXP3 geni promotor bölgesi -3499A/G polimorfizmi ile osteoartrit riski arasındaki ilişki bir Türk popülasyonunda araștırılmıştır.

Yöntem: Çalışma grubu, 3. evre 50 ve 4. evre 100 OA hastasından, kontrol grubu ise 150 sağlıklı bireyden oluşmuştur. FOXP3 genotipleri PCR-RFLP yöntemleri kullanılarak elde edilmiştir.

Bulgular: Sonuçlarımız istatistiksel olarak OA riski ve FOXP3 geni promotor bölgesi -3499A/G polimorfizmi arasında anlamlı bir ilișki olmadığını göstermiștir. Kontrol grubunda doğal tip AA genotipi \%63, polimorfik AG \%31 ve GG genotipi oranı $\% 6$ bulunurken çalışma gurubunda bu oranlar sırasıyla \%56, \%37 ve $\% 7$ olarak bulunmuştur.

Sonuç: Kadınlarda erkeklere oranla daha sık gözlenmiştir ve bu gözlem, önceki çalışmalarda elde edilen sonuçlar ile uyumludur.

Anahtar sözcükler: FOXP3, Osteoartrit, promotor, polimorfizm 


\section{INTRODUCTION}

Osteoarthritis (OA) is one of degenerative chronic joint diseases that pathogenesis has not been clarified exactly. Over the age of $60,10 \%$ of men and $18 \%$ of women are affected by the disease. OA causes joint destriction in cartilaginous joint and proliferative changes in surrounding bone and soft tissues by holding synovial joints. It is thought that genetic, environmental, mechanical and endocrine factors contribute to etiology. In addition these, the OA risk is increase by advanced age, diabetes, overweight, joint surgeries and traumas ${ }^{1-5}$. Joint swelling, joint anomalies and pain in the individuals with the disease, decrease the quality of life of the patients ${ }^{6}$.

Epidemiological and genetic studies have shown that genetic factors play an important role in OA. The main strategies used to investigate the role of genetics in OA are familial cluster surveys, twin studies, linkage analysis and genetic association studies ${ }^{7}$. A large number of genomic regions in 2 , $4,6,7,11,16,19$ and $X$ chromosomes have been linked with OA susceptibility ${ }^{7}$.

Although previous epidemiological studies suggest that polymorphisms in different genes contribute to the development of $\mathrm{OA}$ by individually or in combination, there is no general opinion about this issue yet. It is unknown that which genetic changes, which alignment and whether single or not have contributed to the onset or development of $\mathrm{OA}^{8}$. It is suggested that inflammation which seen in synovial membranes in OA, triggers inflammationpromoting mediators 9 . In study of rheumatoid arhritis (RA), one of the autoimmune diseases, it has been determined that variations in the FOXP3 (transcription factor forkhead box P3) promoter region linked with inflammation increase the risk of the disease ${ }^{10}$. Other studies suggested that polymorphic variations in members of the Toll-like receptor family are expressed in immune system cells, increase OA risk ${ }^{10,11}$. FOXP 3 is a member of the "forkhead winged-helix transcription factor" family. The human FOXP3 gene is 1296 bp in length and consists of 11 exons. FOXP3 encodes a protein containing 431 amino acids, is located on the short arm of chromosome X (Xp11.23) and undergoes $\mathrm{X}$-chromosome inactivation ${ }^{12,13}$. The FOXP3 gene encodes a transcription factor that is thought to be crucial for the development and function of regulatory $\mathrm{T}$ (Treg) cells ${ }^{14}$. FOXP3 regulate development and function of a subset of $\mathrm{CD}^{+} \mathrm{T}$ cells that express Treg cells CD25 (IL-2 receptor $\alpha$ chain). Treg suppresses the proliferation of autoreactive lymphocytes both in the thymus and around the thymus by manner of cell-cell interaction. Thus FOXP3 contributes to natural tolerance to its own antigens by mediating development of Tregs ${ }^{15}$.

There are five SNPs (single nucleotide polymorphism) in the promoter region of FOXP3: -924A/G (rs2232365), -1383C/T (rs2232364), 2383C/T (rs3761549), -3279C/A (rs3761548) and $-3499 \mathrm{~A} / \mathrm{G}$ (rs3761547) [16]. In our case-control study, we investigated whether $\mathrm{A} / \mathrm{G}$ polymorphism in the FOXP3 promoter -3499 region is a risk factor for OA.

\section{MATERIAL AND METHODS Patients}

Patient and control group consisted of 300 (150 patient and 150 healthy) individuals who were applied to the Cumhuriyet University, Medical Faculty, Department of Orthopedics and Traumatology. While the patient group consisted of 150 patients who were diagnosed with OA, 150 individuals from the control group who are not diagnosed with OA, have no autoimmune family history and no chronic disease. The study was approved by Cumhuriyet University Ethical Committe (Decision number: 2015-06/02). Before the samples were collected, approval form was taken from the patients and the control group.

\section{Genotyping}

From each individual, $10 \mathrm{ml}$ blood samples were taken and their DNA was isolated by salting-out method $^{17}$. The FOXP3 promoter region was amplified by polymerase chain reaction (PCR) to include the region -3499 . Primer sequences were forward (5'-CTCTGGCTCTCCATGCATGT-3') and reverse (5'TGCAGGGCTTCAAGTTGACAG- $3^{\prime}$ ). The method for PCR included an initial denaturing at $94^{\circ} \mathrm{C}$ for $4 \mathrm{~min}$, followed by 30 cycles at $94^{\circ} \mathrm{C}$ for $1 \mathrm{~min}, 56^{\circ} \mathrm{C}$ for $30 \mathrm{~s}, 72^{\circ} \mathrm{C}$ for $30 \mathrm{~s}$ with a final extension at $72^{\circ} \mathrm{C}$ for $7 \mathrm{~min}$. The resulting $158 \mathrm{bp}$ amplicons were incubated with PvuII restriction endonuclease enzyme at $37^{\circ} \mathrm{C}$ for 1 hour and then separated on agarose gel. For the AG genotype $158+123+35 \mathrm{bp}$ fragments, for the GG genotype $123+35$ bp fragments and for wild type AA genotype 158 bp fragment were analyzed ${ }^{15}$.

\section{Statistical Analysis}

The data were analyzed using the SPSS 23.0 (SPSS, Chicago, IL, USA) program. Chi square and Fisher's exact tests were used to compare the data. OR and \%95 confidence intervals for obtained results were given. $\mathrm{p}<0.05$ was considered significant in all tests. 


\section{RESULTS}

Patient and control group characteristics in this study are given in Table 1. According to Table 1, while age distribution of patients and control group is statisticaly unsignificant, in terms of gender, OA is occured statisticaly higher in female. While $\% 33$ of the patients are in third grade of OA, $\% 67$ of the patients are in fourth grade.

Table 1: OA patients and control group demografic data

\begin{tabular}{rlll}
\hline & Control $(\mathbf{n}=\mathbf{1 5 0})$ & Patient $(\mathbf{n = 1 5 0})$ & p value \\
\hline $\begin{array}{l}\text { Age } \\
\text { Gender }\end{array}$ & $61 \pm 11.98$ & $63 \pm 10,77$ & $>0.05(0.93)$ \\
Female & $81(54 \%)$ & $110(73 \%)$ & $<0.05(0.00051)$ \\
Male & $69(46 \%)$ & $40(26.7 \%)$ & \\
Stage of Disease & & & \\
Grade 3 & & $50(33.3 \%)$ & \\
Grade 4 & & $100(66.7 \%)$ & \\
\hline
\end{tabular}

When we investigated genotypes of patient and control group whether or not FOXP3 -3499 A/G polymorphism, our results show that wild type AA is found almost equal value in patient and control group. Wild type was seen in $56 \%$ of patients group and $63 \%$ of control group. AG heterozygote is found $56 \%$ and $47 \%$ in patient and control groups respectively, and GG homozygote polymorphic genotype is found $10 \%$ and $8 \%$ in patient and control groups, respectively. When we evaluate these data statistically, significant differences with two groups are not found. Genotypes distribution, $\mathrm{p}$ value and risk ratio and confidence interval were shown in Table 2.

Table 2: FOXP3 promotor region -3499 A/G genotype data according to OA patient and control group distribution

\begin{tabular}{lllll}
\hline Genotype & Control $(\mathbf{n = 1 5 0})$ & Patient $(\mathbf{n = 1 5 0})$ & p value & OR (95\% CI) \\
\hline AA & $95(63 \%)$ & $84(56 \%)$ & & \\
AG & $47(31 \%)$ & $56(37 \%)$ & 0.22 & $1.34(0.82-2.19)$ \\
GG & $8(6 \%)$ & $10(7 \%)$ & 0.49 & $1.42(0.52-3.99$ \\
Genotype & & & & \\
AA & $95(63 \%)$ & $84(56 \%)$ & & \\
AA+AG & $55(37 \%)$ & $66(44 \%)$ & 0.19 & $1.35(0.85-2.16)$ \\
Allele & & & & \\
A & $237(79 \%)$ & $224(7 \% 4)$ & 0.21 & $1.27(0.87-1.87)$ \\
G & $63(\% 21)$ & $76(\% 26)$ & & \\
\hline
\end{tabular}

When we investigated association between disease stage and FOXP3 promotor region polymorphism, we observed that 100 of total 150 patients are in 4th grade, 50 patients are in 3rd grade of OA. There is no statistically significant difference between disease stage and the interested polymorphism (Table 3). Genotype distribution of the patient and control group is similar $(\mathrm{p}>0.05)$. 
Table 3: FOXP3 promoter region -3499 A/G genotype and distribution of allel frequency in OA disease stage

\begin{tabular}{llllllll}
\hline Genotype & $\begin{array}{l}\text { Control } \\
\mathbf{n = 1 5 0}(\boldsymbol{\%})\end{array}$ & $\begin{array}{l}\text { OA Stage } \\
\mathbf{3} \mathbf{n = 5 0}(\boldsymbol{\%})\end{array}$ & $\begin{array}{l}\mathbf{p} \\
\text { value }\end{array}$ & OR $(\mathbf{9 5 \%} \mathbf{C I})$ & $\begin{array}{l}\text { OA Stage } \\
\mathbf{4} \mathbf{n = 1 0 0} \\
(\boldsymbol{\%})\end{array}$ & $\begin{array}{l}\mathbf{p} \\
\text { value }\end{array}$ & OR (95\%CI) \\
\hline AA & $95(63)$ & $30(60)$ & & & $62(62)$ & & \\
AG & $47(31)$ & $17(34)$ & 0.69 & $1.14(0.56-2.28)$ & $31(31)$ & 0.96 & $1.01(0.57-1.76)$ \\
GG & $8(6)$ & $3(7)$ & 0.78 & $1.18(0.24-4.63)$ & $7(7)$ & 0.59 & $1.38(0.44-3.99)$ \\
Genotype & & & & & & & \\
AA & $95(63)$ & $30(60)$ & & & $62(62)$ & & \\
AG+GG & $55(37)$ & $20(40)$ & 0.67 & $1.15(0.59-2.22)$ & $38(38)$ & 0.83 & $1.05(0.62-1.78)$ \\
Allele & & & & & & & \\
A & $237(79)$ & $77(77)$ & 0.66 & $1.12(0.64-1.92)$ & $155(78)$ & 0.68 & $1.09(0.70-1.68)$ \\
G & $63(21)$ & $23(23)$ & & & $45(22)$ & & \\
\hline
\end{tabular}

\section{DISCUSSION}

Studies investigated OA-polymorphism assosiation are showed that fifty different genes are associated with OA. However, the gene variations in OA undetermined in all studies, so debate about this issue is countinued. While COL6A4P1 polymorphism (collagen type VI, alpha 4 pseudogene 1) increases OA risk in Asian population, the same risk is not seen in Caucasion populations ${ }^{18}$. Such as COL11A1, VEGF, GDF5 and IL8 gene polymorphisms in different population studies are described as risk factors. However OA linked genetic polymorphism studies don't make a consensus, researchers concentrate on different gene studies ${ }^{18-22}$. One of these genes is FOXP3. Polymorphisms at promoter region are introduced that can be important for rheumotoid arthritis (RA). Recent studies were reported that association with FOXP3 promoter region polymorphisms and various diseases especially autoimmun diseases ${ }^{23}$. Nevertheless OA isn't autoimmune disease like RA, recent studies about OA supported that Treg cells aggregate at joints like RA. Polymorphisms described in FOXP3 promotor cause deficient of Treg cells and in this way immun reactions improve 9, 11, 23, 24, 25. In another study that compared with OA and RA, Treg cells equally tranfers to synovial membrane and synovial fluid in joints both of OA and RA and Treg aggregation is not spesific to artritis with inflammation ${ }^{26}$.

Based on literture, FOXP3 promoter -3499 A/G polymorphism that is suggested as risk factor is investigated whether is associated with OA or not. Our results show that there is no association between 3rd and 4th grade OA and FOXP3 -3499 A/G polymorphism (Table 3 ).

When we analyzed demographic data, female patients are seen statistically high prevalance compared to male patients with OA and this result is compatible with many studies. While control group and patient group distribution was investigated according to FOXP3 promotor -3499 A/G polymorphism, it is similar to other populations. Wild type AA genotype is $65 \%$, heterozygote AG genotype is $28 \%$, homozygote GG genotype is $4-7 \%$ in Asian population. In Caucasion population AA is $60 \%, \mathrm{AG}$ is $35 \%$ and GG is $3-5 \%[15,27,28]$. In our study we found that $\mathrm{AA}$ is $63 \%$, AG is $31 \%$ and $\mathrm{GG}$ is $6 \%$ (Table 3 ).

In this study first time, FOXP3 promoter region $3499 \mathrm{~A} / \mathrm{G}$ polymorfism is investigated in Turkish OA patients. Our results show that there is no association between disease risk and interested polymorphism. In different disease there is an association with four different SNPs in FOXP3 promoter region. To study these SNPs in OA may present clear evidience.

\section{Acknowledgements}

The work was supported by grants from Cumhuriyet University Scientific Research Unit. (Project No: T702).

\section{REFERENCES}

1. Zhang Y, Jordan JM. Epidemiology of Osteoarthritis. Clin Geriatr Med 2010; 26: 35569.

2. Bijlsma JW, Berenbaum F, Lafeber FP. Osteoarthritis: an update with relevance for clinical practice. Lancet 2011; 377(9783): 2115-26.

3. Lotz MK, Kraus VB. New developments in osteoarthritis. Posttraumatic osteoarthritis: pathogenesis and pharmacological treatment options. Arthritis Res Ther 2010; 12: 211.

4. Sowers MR, Kavonen-Gutierrez CA. The evolving role of obesity in knee osteoarthritis. Curr Opin Rheumatol 2010; 22: 533-7. 
5. Felson DT. An update on the pathogenesis and epidemiology of osteoarthritis. Radiol Clin N Am 2004; 42: 1-9.

6. Dieppe PA, Lohmander LS. Pathogenesis and management of pain in osteoarthritis. Lancet 2005; 365(9463): 965-73.

7. Sezgin M. Osteoartrit: Genetik. Türkiye Klinikleri Fiziksel Tip Rehabilitasyon Osteoartrit Özel Sayı 2012; 5: 8-14.

8. Valdes AM, Doherty M, Spector TD. The additive effect of individual genes in predicting risk of knee osteoarthritis. Ann Rheum Dis 2008; 67: 124-7.

9. Guo SY, Ding YJ, Li L, Zhang T, Zhang ZZ, Zhang ES. Correlation of $\mathrm{CD} 4^{+} \mathrm{CD} 25^{+} \mathrm{FoxP} 3^{+}$Treg with recovery of joint function after total knee replacement in rats with osteoarthritis. Genetics and Molecular Research 2015; 14: 7290-6.

10. Paradowska-Gorycka A, Jurkowska M, FelisGiemza A, Romanowska-Prochnicka K, Manczak M, Maslinski S, Olesinska M. Genetic polymorphisms of FoxP3 in patients with rheumatoid arthritis. J Rheumatol 2015; 42: 2.

11. Balbaloglu O, Sabah Ozcan S, Korkmaz M, Y1lmaz N. Promoter polymorphism (T-1486C) of TLR-9 gene is associated with knee osteoarthritis in a Turkish population. J Orthop Res 2017; 35: 2484-9.

12. Gambineri E, Torgerson TR, Ochs HD. Immune dysregulation, polyendocrinopathy, enteropathy, and X-linkedinheritance (IPEX), a syndrome of systemic autoimmunity caused by mutations of FOXP3, a critical regulator of Tcell homeostasis. Curr Opin Rheumatol 2003; 15: 430-5.

13. Fontenot JD, Rasmussen JP, Williams LM, Dooley JL, Farr AG, Rudensky AY. Regulatory $\mathrm{T}$ cell lineage specification by the forkhead transcription factor foxp3. Immunity $2005 ; 22$ : 329-41.

14. Oda JMM, Hirata BKB, Guembarovski RL, Watanabe MAE. Genetic polymorphism in FOXP3 gene: imbalance in regulatory T-cell role and development of human diseases. J Genet 2013; 92: 163-71.

15. Eastell T, BSPAR Study Group, Hinks A, Thomson W. SNP's in the FoxP3 gene region show no association with juvenile idiopathic arthritis in UK caucasian population. Rheumatology (Oxford) 2007; 46: 1263-5.

16. Bassuny WM, Ihara K, Sasaki Y, Kuromaru R, Kohno H, Matsuura N, Hara T. A functional polymorphism in the promoter/enhancer region of the FOXP3/Scurfin gene associated with type 1 diabetes. Immunogenetics 2003; 55: 149-56.
17. Miller SA, Dykes DD, Polesky HF. A simple salting out procedure for extracting DNA from human nucleoted cells. Nucleic Acids Res 1988; 16: 1215.

18. Huang Q. Genetic study of complex diseases in the post-GWAS era. J Genet Genomics 2015; 42: 87-98.

19. Raine EV, Dodd AW, Reynard LN, Loughlin J. Allelic expression analysisof the osteoarthritis susceptibility gene COL11A1 in human joint tissues. BMC Musculoskelet Disord 2013; 14: 85.

20. Bravata V, Minafra L, Forte GI, Cammarata FP, Saporito M, Boniforti F, Lio D, Gilardi MC, Messa C. DVWA gene polymorphisms and osteoarthritis. BMC Res Notes 2015; 8: 30.

21. Miyamoto Y, Shi D, Nakajima M, Ozaki K, Sudo A, Kotani A, Uchida A, Tanaka T, Fukui N, Tsnoda T, Takahashi A, Nakamura Y, Jiang $\mathrm{Q}$, Ikegawa S. Common variants in DVWA on chromosome 3p24.3 are associated with susceptibility to knee osteoarthritis. Nat Genet 2008; 40: 994-8.

22. Takahashi H, Nakajima M, Ozaki K, Tanaka T, Kamatani N, Ikegawa S. Prediction model for knee osteoarthritis based on genetic and clinical information. Arthritis Res Ther 2010; 12: R187.

23. Wildin RS, Smyk-Pearson S, Filipovich AH. Clinical and molecular features of the immunodysregulation, polyendocrinopathy, enteropathy, X linked (IPEX) syndrome. J Med Genet 2002; 39: 537-45.

24. Feng E, Gao H, Su W, Yu C. Immunotherapy of rat glioma without accumulation of $\mathrm{CD} 4{ }^{+} \mathrm{CD} 25^{+} \mathrm{FOXP} 3^{+}$regulatory $\mathrm{T}$ cells. Neural Regen Res 2012; 7: 1498-506.

25. Sun L, Wu J, Yi S. Foxp3 is critical for human natural $\mathrm{CD}^{+} \mathrm{CD} 25^{+}$regulatory $\mathrm{T}$ cells to suppress alloimmune response. Transpl Immunol 2012; 26: 71-80.

26. Moradi B, Schnatzer P, Hagmann S, Rosshirt N, Gotternbarm T, Kretzer JP, Thomsen M, Lorenz HM, Zeifang F, Tretter T. $\mathrm{CD} 4^{+} \mathrm{CD} 25^{+} /$highCD127low/- regulatory $\mathrm{T}$ cells are enriched in rheumatoid arthritis and osteoarthritis joints-analysis of frequency and phenotype in synovial membrane, synovial fluid and peripheral blood. Arthritis Res Ther 2014; 16: R97.

27. Inoue $N$, Watanabe $M$, Morita M, Tomizawa R, Akamizu T, Tatsumi K, Hidaka Y, Iwatani Y. Association of functional polymorphisms related to the transcriptional level of FOXP3 with prognosis of autoimmune thyroid diseases. Clin Exp Immunol 2010; 162: 402-6.

28. Zhang L, Zhang Y, Desrosiers M, Wang C, Zhao Y, Han D. Genetic association study of 
FOXP3 polymorphisms in allergic rhinitis in a

Chinese population. Hum Immunol 2009; 70: 930-4. 